MYOCARDIAL PROTECTION AND THE $\mathrm{K}_{\text {ATP }}$ CHANNEL 


\section{DEVELOPMENTS IN CARDIOVASCULAR MEDICINE}

121. S. Sideman, R. Beyar and A. G. Kleber (eds.): Cardiac Electrophysiology, Circulation, and Transport. Proceedings of the 7th Henry Goldberg Workshop (Berne, Switzerland, 1990). 1991. ISBN 0-7923-1145-0.

122. D. M. Bers: Excitation-Contraction Coupling and Cardiac Contractile Force. 1991. ISBN 0-7923-1186-8.

123. A.-M. Salmasi and A. N. Nicolaides (eds.): Occult Atherosclerotic Disease. Diagnosis, Assessmentand Management. 1991. ISBN 0-7923-1188-4.

124. J. A. E. Spaan: Coronary Blood Flow. Mechanics, Distribution, and Control. 1991. ISBN 0-7923-1210-4.

125. R. W. Stout (ed.): Diabetes and Atherosclerosis. 1991. ISBN 0-7923-1310-0.

126. A. G. Herman (ed.): Antithrombotics. Pathophysiological Rationale for Pharmacological Interventions. 1991. ISBN 0-7923-1413-1.

127. N. H. J. Pijls: Maximal Myocardial Perfusion as a Measure of the Functional Significance of Coronary Arteriogram. From a Pathoanatomic to a Pathophysiologic Interpretation of the Coronary Arteriogram. 1991. ISBN 0-7923-1430-1.

128. J. H. C. Reiber and E. E. v. d. Wall (eds.): Cardiovascular Nuclear Medicine and MRI. Quantitation and Clinical Applications. 1992. ISBN 0-7923-1467-0.

129. E. Andries, P. Brugada and R. Stroobrandt (eds.): How to Face "the Faces" of Cardiac Pacing. 1992. ISBN 0-7923-1528-6.

130. M. Nagano, S. Mochizuki and N. S. Dhalla (eds.): Cardiovascular Disease in Diabetes. 1992. ISBN 0-7923-1554-5.

131. P. W. Serruys, B. H. Strauss and S. B. King III (eds.): Restenosis after Intervention with New Mechanical Devices. 1992. ISBN 0-7923-1555-3.

132. P. J. Walter (ed.): Quality of Life after Open Heart Surgery. 1992. ISBN 0-7923-15804.

133. E. E. van der Wall, H. Sochor, A. Righetti and M. G. Niemeyer (eds.): What is new in Cardiac Imaging? SPECT, PET and MRI. 1992. ISBN 0-7923-1615-0.

134. P. Hanrath, R. Uebis and W. Krebs (eds.); Cardiovascular Imaging by Ultrasound. 1992. ISBN 0-7923-1755-6.

135. F. H. Messerli (ed.): Cardiovascular Disease in the Elderly, 3rd ed. 1992. ISBN 0-7923-1859-5.

136. J. Hess and G. R. Sutherland (eds.); Congenital Heart Disease in Adolescents and Adults. 1992. ISBN 0-7923-1862-5.

137. J. H. C. Reiber and P. W. Serruys (eds.): Advances in Quantitative Coronary Arteriography. 1993. ISBN 0-7923-1863-3.

138. A.-M. Salmasi and A. S. Iskandrian (eds.): Cardiac Output and Regional Flow in Health and Disease. 1993. ISBN 0-7923-1911-7.

139. J. H. Kingma, N. M. van Hemel and K. I. Lie (eds.): Atrial Fibrillation, a Treatable Disease? 1992. ISBN 0-7923-2008-5.

140. B. Ostadal, N. S. Dhalla (eds.): Heart Function in Health and Disease. 1993. ISBN 0-7923-2052-2.

141. D. Noble and Y.E. Earm (eds.): Ionic Channels and Effect of Taurine on the Heart. Proceedings of an International Symposium (Seoul, Korea, 1992). 1993. ISBN 0-79232199-5.

142. H.M. Piper and C.J. Preusse (eds.): Ischemia-reperfusion in Cardiac Surgery. 1993. ISBN 0-7923-2241-X.

143. J. Roelandt, E.J. Gussenhoven and N. Bom (eds.): Intravascular Ultrasound. 1993. ISBN 0-7923-2301-7.

144. M.E. Safar and M.F. O'Rourke (eds.): The Arterial System in Hypertension. 1993. ISBN 0-7923-2343-2.

145. P. W. Serruys, D.P. Foley and P.J. de Feyter (eds.): Quantitative Coronary Angiography in Clinical Practice. 1993. ISBN 0-7923-2368-8.

146. J. Candell-Riera and D. Ortega-Alcalde (eds.): Nuclear Cardiology in Everyday Practice. 1993. ISBN 0-7923-2374-2.

147. P. Cummins (ed.): Growth Factors and the Cardiovascular System. 1993. ISBN 79232401-3.

148. K. Przyklenk, R.A. Kloner and D.M. Yellon (eds.): Ischemic Preconditioning: The Concept of Endogenous Cardioprotection. 1993. ISBN 0-7923-2410-2. 
Editors

Derek M. Yellon, Ph.D., DSc. MRCP(Hon), FESC, FACC

Professor of Cellular Cardiology

Head of the Division of Cardiology \&

Director of the Hatter Institute

University College London Medical School \& Hospitals, London, United Kingdom

Garrett J. Gross, B.S., M.S., Ph.D.

Professor of Pharmacology \& Toxicology

Department of Pharmacology \& Toxicology

Medical College of Wisconsin

8701 Watertown Plank Road

Milwaukee 53226, USA

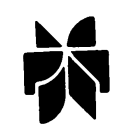

KLUWER ACADEMIC PUBLISHERS

Boston Dordrecht London 
Distributors for North America:

Kluwer Academic Publishers

101 Philip Drive

Assinippi Park

Norwell, Massachusetts 02061 USA

Distributors for all other countries:

Kluwer Academic Publishers Group

Distribution Centre

Post Office Box 322

3300 AH Dordrecht, THE NETHERLANDS

\section{Library of Congress Cataloging-in-Publication Data}

Myocardial protection and the KATP channel / editors, Derek M.Yellon, Garrett J. Gross.

p. cm. -- (Developments in cardiovascular medicine : 179) Includes index.

On t.p. "ATP" is subscript.

ISBN-13: 978-1-4613-8055-9

e-ISBN-13: 978-1-4613-0453-1

DOI: $10.1007 / 978-1-4613-0453-1$

1. Coronary heart disease--Chemotherapy--Congresses. 2. Calcium channels--Congresses. 3. Cardiovascular agents--Congresses.

I. Yellon, Derek M. II. Gross, Garrett J. III. Series.

[DNLM: 1. Myocardial Ischemia--metabolism--congresses.

2. Potassium Channels--metabolism--congresses. W1 DE997VME v. 179 1995 / WG 300 M99767 1995]

RC685.C6M976 1995

616.1'23--dc20

DNLM/DLC

for Library of Congress

Copyright ${ }^{\odot} 1995$ by Kluwer Academic Publishers

Softcover reprint of the hardcover 1st edition 1995

All rights reserved. No part of this publication may be reproduced, stored in a retrieval system or transmitted in any form or by any means, mechanical, photo-copying, recording, or otherwise, without the prior written permission of the publisher, Kluwer Academic Publishers, 101 Philip Drive, Assinippi Park, Norwell, Massachusetts 02061

Printed on acid-free paper. 


\section{Table of Contents}

Chapter 1: The Biology of $\mathrm{K}_{\mathrm{ATP}}$ channels

NB Standon

Chapter 2: $\quad$ Vascular Pathology and the $\mathrm{K}_{\mathrm{ATP}}$ channel

U Quast \& S Glocker

Chapter 3: Activation of the ATP-sensitive potassium channels:

A novel pharmacological approach to myocardial protection? 51

DJ Hearse

Chapter 4: The relationship between the KATP channel and Myocardial Preconditioning

GJ Gross \& DM Yellon

Chapter 5: Potassium channel activation and arrhythmogenicity

MJ Janse \& AAM Wilde

Chapter 6: Clinical Exploitation of the $\mathrm{K}_{\mathrm{ATP}}$ channel

H Purcell \& K Fox

Chapter 7: Is there a potential role for the $\mathrm{K}_{\mathrm{ATP}}$ openers in the treatment of Angina?

LH Opie

Chapter 8: $\quad \mathrm{K}_{\mathrm{ATP}}$ channel exploitation for treating myocardial ischemia:Future directions?

GJ Grover 


\section{Contributing Authors}

Professor Nicholas B Standen MA, PhD.

Professor of Physiology and Director

Ion Channel Group

Department of Cell Physiology \& Pharmacology

University of Leicester

P.O.Box 138

University Road

Leicester LE1 9HN

United Kingdom

Professor Ulrich Quast $\mathrm{PhD}$.

Head of Molecular Pharmacology Section

Department of Pharmacology

Section of Molecular Pharmacology

Medical Faculty

University of Tubingen

Wilhelmstr 56

D-72074 Tubingen

Germany

Mr Stefan Glocker

Department of Pharmacology

Section of Molecular Pharmacology

Medical Faculty

University of Tubingen

Wilhelmstr 56

D-72074 Tubingen

Germany

Professor David J Hearse Bsc, PhD, DSc, FACC.

Professor of Cardiuac Biochemistry and

Director of the Cardiovascular Research Unit

The Rayne Institute

St Thomas' hospital

London SE1 7EH,

United Kingdom

Dr Garrett J Gross BS, MS, PhD.

Professor of Pharmacology \& Toxicology

Department of Pharmacology \& Toxicology

Medical College of Wisconsin

8701 Watertown Plank Road

Milwaukee 53226

USA

Professor Derek M Yellon PhD, Dsc, MRCP(Hon), FESC, FACC

Professor of Cellular Cardiology

Head of the Division of Cardiology \&

Director of the Hatter Institute

University College London Medical School \& Hospitals.

Grafton Way

London, WCIE 6DB

United Kingdom. 
viii

Professor Dr. Michiel .J Janse MD, PhD

Professor of Experimental Cardiology

Department of Clinical and Experimental Cardiology,

M-0-052 Academic Medical Center

University of Amsterdam

Meibergdreef 9

1105 AZ Amsterdam ZO

The Netheralnds

Dr Authur M Wilde MD, PhD.

Consultant Cardiologist

Department. of Clinical and Experimental Cardiology,

M-0-0-52 Academic Medical Center

University of Amsterdam

Meibergdreef 9

1105 AZ Amsterdam ZO

The Netheralnds

Dr Henry J Purcell MB Bch, PhD.

Senior Research Fellow

The Royal Brompton Hospital

Sidney Street

London SW3 6NP

United Kingdom

Dr Kim M Fox MD, FRCP, FESC.

Consultant Cardiologist

The Royal Brompton Hospital

Sidney Street

London SW3 6NP

United Kingdom

Professor Lionel H Opie MD D Phil. FRCP.

Professor of Medicine and

Director of the Medical Research Council Ischaemic

Heart Disease Research Unit

University of Cape Town

Medical School

Observatory 7925

Cape Town

South Africa

Dr Gary J. Grover BS, MS, PhD.

Senior Principal Scientist

Department of Pharmacology

Bristol-Myers Squibb Pharmaceutical Research Institute

Route 206 \& Provinceline Road

Princeton, N.J. 08543-400

USA 


\section{Preface \& Acknowledgements}

With the continual interest in developing means of protecting the ischemic and reperfused myocardium, as well as the advent of a particular excitement in the role that the $\mathrm{K}_{\mathrm{ATP}}$ channel may play in this protection, we the editors, felt that it was both timely and appropriate that a concise, state of the art book, addressing this topic should be written.

A number of the concepts discussed in the following chapters were convened at a round table meeting held at Cliveden, England in 1995 under the auspices of the Cellular Biology Working Group of the European Society of Cardiology. We are grateful to Rhone Poulenc Rorer and Merck Lipha for providing an educational grant to sponsor the round table meeting and to support the publication of this book.

We also sincerely thank the Department of Academic \& Clinical Cardiology at University College London and the Department of Pharmacology and Toxicology at the Medical College of Wisconsin for providing the academic environment that has enabled us to pursue our research and educational endeavours. On a more personnel note both Derek \& Garrett particularly want to express their grateful thanks to Luci and Carol for their continued patience and understanding of our sometimes misguided drive to pursue our indulgence for academic gratification!

Finally our most sincere thanks must go to our distinguished contributors who despite the enormous pressures which are continually placed upon them all made contributions of the highest calibre. All the authors felt that a book addressing this important and highly topical subject should proceed without delay which we are delighted to say has allowed this volume to be published within one year of its conception.

Derek M Yellon

Garrett J Gross 